Watkins

\title{
The Politics of Nostalgia: Colorization, Spectatorship and the Archive
}

Colorization describes the digitization and retrospective addition of color to photographic and film materials (celluloid nitrate, glass negatives) initially made and circulated in a black-and-white format. Revisiting the controversial 1980s colorization of 24 classic Hollywood studio titles, which incited debate over questions of copyright, authorship and artistic expression, this essay examines the use of colorization to interpret museum collections for new audiences. The aesthetics of colorization have been criticized for prioritizing image content over the history of film technologies, practices and exhibition. An examination of They Shall Not Grow Old (Jackson, 2018) finds a use of digital editing and coloring techniques in the colorization of First World War film footage held in the Imperial War Museum archives that is familiar to the director's fiction films. Jackson's film is a commemorative project, yet the "holistic unity" of authorial technique operates across fragments of archive film and photographs to imbricate of fiction and nonfiction, signaling vital questions around the ethics and ideologies of "natural color", historiography, and the authenticity of materials and spectator experience.

Keywords

COLOR

COLORIZATION

ARCHIVAL IMAGES

PHOTOGRAPHY

FIRST WORLD WAR

PETER JACKSON

Date submitted: $26 / 5 / 2021$

Date accepted: 3/11/2021

Liz Watkins

e.i.watkins@leeds.ac.uk

orcid.org/0000-0003-2093-6327

Research Fellow, University of Leeds. Her research interests include color, its theories, technologies, and materiality in cinema; sexuality and the image; contingency and photographic experiments in polar climates (c.1898-1918); and the history and ethics of colorization and the archive. She co-edited Color and the Moving Image: History, Theory, Aesthetics, Archive (Routledge, 2013), British Colour Cinema (Bloomsbury 2013) and Gesture and Film: Signalling New Critical Perspectives (Routledge, 2017). Her current book project is on theories of color in cinema. 


\section{Introduction}

The digital manipulation and circulation of still and moving images has become prevalent, yet, the colorization of archive photographs and films has remained a contentious issue. Colorization describes the digitization and retrospective addition of color to photographic and film materials (celluloid nitrate, glass plate negatives) that were initially made and circulated in a black-andwhite format. Whilst the controversial colorization of 24 classic Hollywood studio titles in the 1980s incited debate around authorship, copyright and artistic expression, the recent resurgence in colorization projects has focused on nonfiction photographs and newsreels. 'Marina Amaral's colorization of over 200 photographs in print publications co-authored with Dan Jones-The Colour of Time: A New History of the World 1850-1960 (2018) and All the World Aflame: the Long War 1914-1945 (2020) - and the television documentary Auschwitz Untold: In Colour (Fulwell 73/ Channel $4,2020)$ emerged alongside Wolfgang Wild and Jordan Lloyd's History as they Saw it: Iconic Moments from the Past in Colour (2018), and Peter Jackson's editing of Imperial War Museum (IWM) archive film in They Shall Not Grow Old (2018). This essay asks: what is at stake in the colorization of nonfiction photographs and film as a form for which the veracity of the image is invested in the indexicality of the photosensitive material? Marina Amaral's note that colorization acts as "an emotional enhancing agent: it magnifies empathy and horror, pity and disgust" (Amaral and Jones 2020, 9) is recalled in Jackson's description of the digital editing and coloring of They Shall Not Grow Old. Jackson describes "the faces of the men as they suddenly became real people," suggesting that the addition of color, diegetic voices and sound to images veiled behind the marks, scratches and grain of the film "is the way to humanise them" (1418 NOW 2019). However, for scholars including Lawrence Napper, there is an irresolute tension between the photochemical film as material record of the physical context of its production and the affective appeal of the digital editing and colorization of archive film. The use of colorization as a mode of interpreting and exhibiting museum collections to new audiences has been criticized for the prioritization of image content over the history of film technologies, practices, and the politics of exhibition. Jackson's use of digital editing and coloring techniques are familiar to his fiction films and used in the colorization of First World War film footage held in the Imperial War Museum archive. This essay reads They Shall Not Grow Old as a commemorative project that inflects the holistic unity of authorial technique across the fragments of archival newsreels and photographs. It examines the imbrication of fiction and nonfiction to signal a series of vital questions around the ethics and ideologies of "natural color," historiography, and the authenticity of materials and spectator experience. Such acts of colorization are in keeping with predominant teleological models of film historiography that, as Thomas Elsaesser (2016) has noted, privilege technical and authorial innovations through the retrospective positioning of the images and techniques that preceded them in terms of lack. Reviews of Jackson's film read the addition of color as bringing the past to life, tangibly closer to us (Murphy 2018). The link between color and life, as Roland Barthes reminds us, is a "purely ideological notion" $(2000,81)$. The use of colorization in the interpretation and exhibition of nonfiction photographs and film, as Paul Grainge notes in "Reclaiming Heritage" (1999), "posits a decline and then appeals to [the 
'restoration' of] a more authentic and politically serviceable" idealized past: a politics of nostalgia that is typified in the reception of projects by Amaral and Jackson. However, Jackson's They Shall Not Grow Old constructs a "natural color" image and narrative form familiar to the Hollywood epic. The selection of archive film, use of digital editing and colorization prioritize a spectatorship contemporary to the centenary of the First World War, yet in doing so, reiterates a tract of white British historiography and representation of flesh tones in the construction of a "natural color" image rather than acknowledging the complex and nuanced history of conflict and the work of women and soldiers from across the British Empire.

\section{Why then? The 1980 s colorization debate}

The contentious colorization of 24 classic Hollywood studio titles, including Casablanca (Michael Curtiz, 1942/ 1988) and It's a Wonderful Life (Frank Capra, 1946/ colorization, 1992) and the Maltese Falcon (John Huston, 1941/ colorization, 1986) sought to revitalize economic interest in the MGM archive following its purchase by Turner Entertainment. The colorized films were intended for broadcast via US Television syndication and averaged $80 \%$ higher rating than their black-and-white counterparts. However, the colorized films invoked a series of questions about the legal rights of ownership, copyright, ethics and the moral rights of authorship and artistic expression (see Grainge 1999; Cooper 1991; Sherman and Dominick 1988; Edgerton 2000). ${ }^{2}$ John Huston, as the director of a selection of the Hollywood films listed for colorization, commented that "it would almost seem as though a conspiracy exists to degrade a national character" (Huston quoted in Edgerton 2000, 27), a reminder that commercial cinema in both its fiction and nonfiction forms is an integral aspect of cultural heritage. The emergence of the National Film Preservation Act 1988 in the USA acknowledged classical Hollywood cinema as part of "what counts as legitimate knowledge and culture" (Grainge 1999, 622), more broadly stipulating that the black-andwhite source materials be preserved unaltered and that acknowledgment of the work of colorization accompany versions to which the process had been applied. In his study of the 1980s colorization debate, Grainge notes the retrospective positioning of the blackand-white films in terms of lack. The retrospective inference of the colorized image as a correction, a return to an aesthetic that could not be achieved at the time of the film's initial production, positions colorization in a narrative of decline and restoration-the loss of historic record or cultural artefactthat is deteriorating, fading, lacking at a time of uncertainty. This discourse is read by Grainge as a form of nostalgia, that is, a "plea for continuity at times of uncertainty" $(1999,622)$, be it the politics and culture of 1980s USA or culturally specific responses to the centenary of the First World War as an international conflict that contextualized the reception of Jackson's They Shall Not Grow Old.

A hierarchy of film history in which newsreels and industrial process films are imagined without an author and so sublimated, has been challenged by the concept of useful cinema (Wasson and Acland 2011). In this context, the colorization of nonfiction photographs and films, as scholars including Tanine Allison (2021), Martyn Jolly (2018) and Elizabeth Edwards (2019) have argued, distracts from the historical specificity of camera technologies, craft, and variations in the scale and context of the image viewed. The aesthetics of the colorized image-the selection of hues, their application 
and effect-in the museal exhibition of archive materials remains to be explored. Jason Gendler's notes on Casablanca indicate that the addition of color could undermine or accentuate the differentiation of character from background, a visual distinction which in a black-and-white image relies on contrasts in light, shadow and pattern (Gendler 2013; Cooper 1991). Further, for Edwards, taking Amaral's The Colour of Time as an example, is "not a book about photography, then, or even photographs as possible historical sources, but an illustrative springboard for a potted global history of the one hundred years from c. 1850 [...] a single image comes to stand for a plenitude of historical, political and cultural complexities" $(2019,331)$. Edwards notes that colorization instils a different set of "colour values" that nuance the composition of the image and the meanings that can be read of it. Lawrence Napper's reading of They Shall Not Grow Old, like that of Tanine Allison, finds that the inference of the photochemical image as an obstruction to viewing pleasure, paired with the articulation of colorization as a form of "restoration," overwrites the political and cultural history of film production (Napper 2018b; Napper 2018c). My analysis of color design and digital editing in Jackson's film, however, begins to unpick the ways in which colorization is imbricated into the politics of nostalgia. The continuities and differences that can be discerned between indexicality of the photographic image and the aesthetics of colorization open a space to discuss the political and cultural context in which the War Office Cinematographic Committee films were made, used by Jackson for They Shall Not Grow Old, and exhibited then and now.

\section{4-18 NOW: They Shall Not Grow Old}

The colorization of IWM film footage in They Shall Not Grow Old formed one of 220 projects produced under the 1418 NOW WWI Centenary Art Commission alongside John Akomfrah's 2018 multiscreen installation Mimesis: African Soldier. Akomfrah's work reminds us of the potential of documentary film and archives to demand critical reflection on the marginalization of communities and social classes in existing historiographies of conflict. Akomfrah's three-screen video installation combined archive materials and newly commissioned film recorded in different geographical locations around the world and was shown in the Imperial War Museum from 2018-19 (Imperial War Museums 2018a). Akomfrah reminds us of our moral obligation to remember the contribution, lives, work and death of people from across British Empire in the First World War on the African continent and Western Front. Mimesis: African Soldier explores the ways that we "orchestrate that understanding [of the past] in the present" (Imperial War Museums 2018a).

The IWM First World War galleries include several instances of colorization across 17 installations that were designed by ISO digital exhibitions, such as the colorization of digitized archive material undertaken by Jordan Lloyd and Wolfgang Wild for the British company Dynamichrome. Colorized footage from Jackson's film They Shall Not Grow Old was included in Life on the Line, a permanent exhibition at IWM North. Jackson examined 100 hours of IWM film footage and 600 hours of oral histories from 114 servicemen, editing and colorizing 30-40 minutes of silent orthochromatic black-and-white film stock (Fig. 1). ${ }^{3}$ The IWM policy on colorization is framed by responsibility for the preservation of photographic and film collections, alongside an obligation to promote understanding of the collection as primary resource for historical research (Sheppard 2021). The IWM, fastidious 


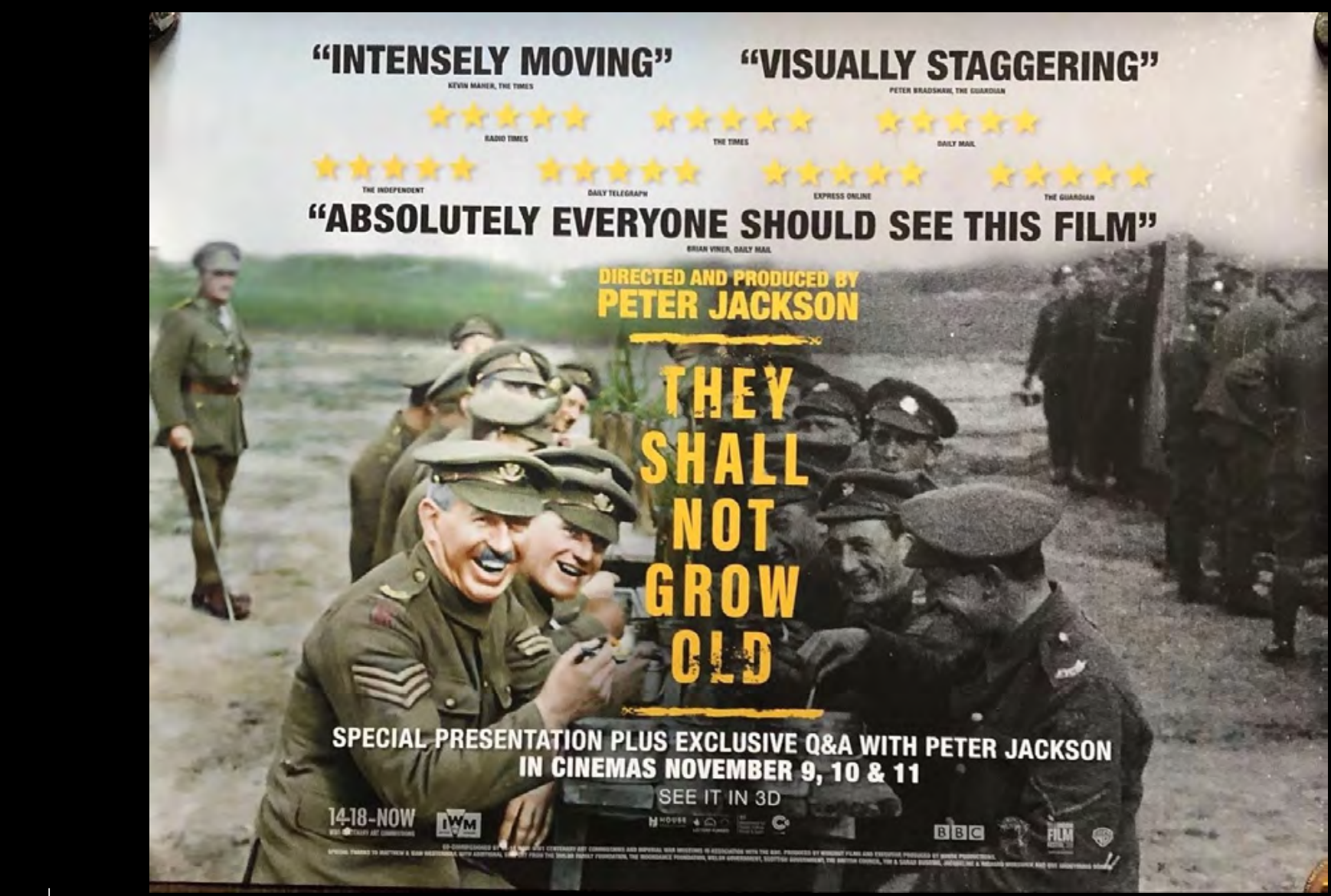

Fig. 1: Poster for They Shall Not Grow Old (Peter Jackson, 2018)

showing the transition from colorization to black-and-white. 
in their approach to preservation and digital access to their photographic and film holdings, acknowledge that permission to colorize material "does not include any endorsement for the historical accuracy of the colourisation" and insist that the "viewer/reader must be clearly aware that they are looking at an artistic rendition of original black and white material" (Imperial War Museums 2018b). The IWM policy on colorization indicates the "gradual blending of an original black and white film or photograph to a newly produced colour image" (Imperial War Museums 2018b) as a method of making the act of colorization visible. The work of film archives and museums lies in conservation, preservation and presentation: sustaining source materials and interpreting them for new audiences. In this context, restoration projects are organized around the exhibition of the film contemporary to its initial release, an instance of viewing that Paolo Cherchi Usai (2001) has theorized in The Death of Cinema as the hypothetical and unattainable Model Image.

Archive policies, including those advocated by the Federation of International Film Archives (FIAF) and the National Film Preservation Board in the USA, similarly require that the work of colorization, which is a material alteration to the image, be stated. The digitization, editing and colorization of archive materials, retains the reels of celluloid nitrate film and glass plate photographs as artefacts, unaltered, but presents a new image of the past.

The materials and meanings of photographic and film archives as they enter the discursive spaces of exhibition have been explored by Philip Rosen in Change Mummified as that between document and diegesis. Rosen writes that Barthes' Camera Lucida initiated a reconsideration of indexicality and pastness in 1970s film theory "beginning from the relation of subjective desire to the configurations of representational technologies" $(2001,175)$. The negotiation of pastness through cultural practices around historicity includes "architectural monuments, museum culture, tourism, and historiography itself, as well as [...] screen media" (Rosen 2001, 77), which this essay discerns in the digitization, editing and colorization of archive materials. Jackson's film remains a commemorative project in which the use of color and digital editing have been noted as both effective and problematic. The use of colorization in They Shall Not Grow Old and the digital editing of analogue filmstock, intricately links private and public forms of viewing "evincing nostalgia for direct, unmediated access [...] the exemplary privatized and particularized experience" (Rosen 2001, 175), which, like the mediation of private grief through public mourning noted by Michael Hammond (2011) in his study of The Battle of the Somme (1916), interlaces emotion with the ideological configurations of narrative form and its representational techniques in the social space of cinema exhibition.

\section{British cinema and the First World War}

The Imperial War Museum archive includes War Office Cinematograph Committee films, which were recorded during the First World War and used in newsreels. The films offered a view of the conditions in which conflict was fought and were shown at cinemas in Britain. The newsreels were advertised as "new and wonderful pictures of the activities of our forces on the Western Front" and screened alongside lantern slide lectures and home propaganda shorts such as "The Money Behind the Guns" and "The War in the Air," which were both produced by the National War Savings Committee in 1917 ("Official Pictures" 1917). Sections of the War 
Office Cinematographic Committee

films were also included in The

Battle of the Somme (1916), which as

Michael Hammond (2011) has noted, testify to the social and political

function of cinema in the circulation

of propaganda. Film offered a form

of memorialization in the absence

of a body, as the repatriation of the

dead was prohibited. The Roll of

Honour films that were shown at local

cinemas enacted a memorializing

process through an ephemeral

medium; the public space of cinema

and solemnity of its form and subject

mediating private grief (see Haggith

2011; Hammond and Williams 2011,

5). Cinema offered a social and

political space for private and public

mourning. Titles such as The Battle

of the Somme combined the existing

aesthetic of the industrial process

film, demonstrating the processes of

operating weaponry and the spectacle

of explosions, with a dramatic

narrative form, however, as Hammond suggests the "reality of war footage did not live up to these expectations for a number of reasons. The use of smokeless explosives was virtually invisible on film, and the nature of warfare across great expanses and the limitations of lens technology and film stock" (Hammond 2011, 23) thwarted the possibility of filming some aspects of the conflict. The film footage was recorded on black-andwhite orthochromatic material, which was "highly sensitive to the blue-end of the visible spectrum and [...] often led to totally overexposed skies if used without filters" (Arnold 2004, 217), rendering blue in a lighter grey tone whilst the color red tended to appear black. ${ }^{4}$ The translation of color from the specific gradients that are characteristic of a black-and-white image on orthochromatic filmstock is deictic of the history of the photographic materials that mediate the evidentiary aspect of the War
Office Cinematographic Committee records. The black-and-white image, described by Wayne Stables, a colorist at Jackson's Weta Digital visual effects company, remained vital to an application of color that was intended to draw out specific details of the image. In They Shall Not Grow Old, colorization is used to both synthesize fragments of film into a cohesive form and highlight details considered salient to the narrative.

Something that can happen when coloring old footage is that if it doesn't look quite right, you actually have to wind it back to see what was happening in black and white [...] Coloring old footage is usually done with broad strokes, but because we were trying to pull out so much of the details, the level of care had to be that much higher (Wayne Stables quoted in Valentini 2019)

\section{The positioning of They Shall} Not Grow Old as a restoration is problematic. ${ }^{5}$ Jackson's film is a commemorative project that reiterates the ideologically complicit aspects of the image and its exhibition by invoking a historically specific association of patriotism and public mourning. The marks of film production and decay, that in viewing archival film are deictic of the past, become a site of disruption to the realist effect of colorization and editing. The addition of color in the production of They Shall Not Grow Old altered the hierarchy of information that was integral to the aesthetic of newsreels, industrial process films and their archives. The 2018 presentation of First World War film footage aligns the spectator with the filmed space by overwriting the history of technology, the labor of film making, and the politics of exhibition and censorship.

However, reviewers of Jackson's film persist in the suggestion that the digital editing and colorization of War 
Office Cinematographic Committee film footage allows the spectator to "see more things than you do in black and white," an opinion that is reiterated by the director: 6

"They didn't see it in black and white so why would we show it in black and white" (Jackson 2018a)

"the Great War as the soldiers themselves saw it" (Jackson in 1418 NOW 2018)

"to show the experience of what it was like to fight in this war [...] the human experience of being in the war." (Jackson 2018b)

"The clarity was such that the soldiers on these films came alive. Their humanity just jumped out at you. This footage has been around for 100 years and these men had been buried behind a fog of damage, a mask of grain and jerkiness and sped-up film. Once restored, it's the human aspect that you gain the most" (Jackson quoted in Murphy 2018)

The inference is that the marks and scratches registered in the photosensitive material of the film image - that trace the history of its making, circulation and storageobstruct the viewer's engagement, whilst the digital alteration and addition of color-that constructs a cinematic illusion of realismemphasize the "human aspect" of the soldiers recorded in the War Office Cinematographic Committee footage.

\section{Surface tension: image, color, text}

The work of the War Office Cinematograph Committee forms a fragmented record of the First World War, which in its disunity of form and image resolution signals the chaos of conflict. The digitization, editing, and colorization of the IWM film footage to produce They Shall Not Grow Old, remediates and synthesizes archival materials into a film text through the holistic expression of the auteur. The strategic deployment of the marks of deterioration, the retrospective depredation of image resolution, and use of color design in They Shall Not Grow Old are techniques familiar to fiction film, positioning the spectator in narrative of mourning and nostalgia. Jackson's editing of the IWM archive adopts the structure of a Hollywood epic. Fragments of oral histories are assembled into a voiceover, like the epistolary form of a historical narrative, to narrate the black-andwhite films recorded by the War Office Cinematographic Committee. Further, the transition into the central section of the film configures the colorized footage in the present tense and as a cinematic illusion of unmediated reality, before returning to the blackand-white images at the end of the film. The editing of photographic documentation of the war into the diegesis of Jackson's film produces what Vivian Sobchack describes as a "subjectively authentic representation of the production of History" (1990, 39; italics in original).

The veracity of the IWM archive film lies in tension with its colorized surface. The indexicality of the photographic, as described by André Bazin, refers to a direct relationship between the image and the filmed space (that camera, at that time in that place), an ontology, which is in operation "no matter how fuzzy, distorted or discoloured, no matter how lacking in documentary value the image may be" (Bazin 1967, 14). Reading Bazin in Change Mummified, Philip Rosen describes the indecipherable aspects of an image being drawn into an "impression of visual likeness through perspective" which "becomes merely a kind of prop" $(2001,17)$, necessary as a point of consistency making the image legible as the depiction of objects in 
space. The image and technology of the camera and filmstrip, as automated registration, form the War Office Cinematographic Committee records.

These material images encode a representation of the space of conflict that also registers the conditions of the environment in which they were made. The selection of images, which use a perspectival plane (trenches, lines of troops) to emphasize visual logic, counters blurring and disorder (Fig. 2).

Images of conflict are entangled with the physical effects of the proximity of the photographer to battle. The shudder of the camera and blurring of the image, as Lawrence Napper (2018a) writes, record the precarious work of War Office Cinematograph Committee cameraman, Geoffrey Malins and John B. MacDowell of the British and Colonial Film Company, operating a hand cranked camera in a trench close to the Western Front.

These filmic remains matter. For scholars such as Rosen (2001), the marks of deterioration that manifest at the level of the image allow the spectator of archive film to invest in the idea of privileged access to the past. The effacement of details by overexposure to light and the blurred movements of conflict are amended, overwritten, by the emphasis on representational form in Jackson's film. The disunity-difficult to watch-of an archive of photographic documentation of conflict has been altered in favor of a more clearly delineated image and narrative.

Jackson's documentary, They Shall Not Grow Old, realigns the concept of authenticity, not as the indexicality of a photographic record, but as that of spectatorial experience by utilizing the IWM archive to construct an image of the First World War that he intends to be as close as possible to the way that the soldiers saw and experienced it (Jackson 2018a). The director's articulation of They Shall Not Grow Old as a "restoration" infers the shudder of film shot at 16 frames per second, the instability and variable speed of a hand-cranked camera, and the grain and decay that make film substrate visible, as disruptive of the spectator's response to the film (Napper 2021). However, these marks are an indexical trace of the physical effects of conflict. It is this - the film as material and technological record of the history of conflict and cinema-that Jackson's work sublimates. The sound track of They Shall Not Grow Old combines oral histories into a coherent account of signing-up, training for trench warfare and the disquiet of returning to civilian life. The historiographic process of selecting and interleaving interviews, foregrounds commonalities and specific geographical tracts to the Western Front, eliding the devastating scale and disparate conflicts that constitute the war. ${ }^{7}$ The film relegates the role of women from industry and agriculture to the realms of home, hospitals, and the sexual anecdotes of soldiers, whilst combatants from across the British Empire and Commonwealth are marginalized by the materials selected. Newly commissioned audio recordings of the conversations deciphered from the silent film by lip-readers, war songs and diegetic sound effects (explosions, the legion of footsteps marching through mud) underscore the events shown. The transition from a black-and-white to colorized image is dramatized as a soldier turns, his hand raised in recognition of the camera and its operator, a gesture that is accompanied by a voice calling "follow me" (Fig. 3). The flicker of the image and prevalence of detritus increases in the frames preceding the visual transition and enact an idea of "restoration" as the return of color and fluidity of movement in the events depicted. The editing of They Shall Not Grow Old distills the breadth of a social 


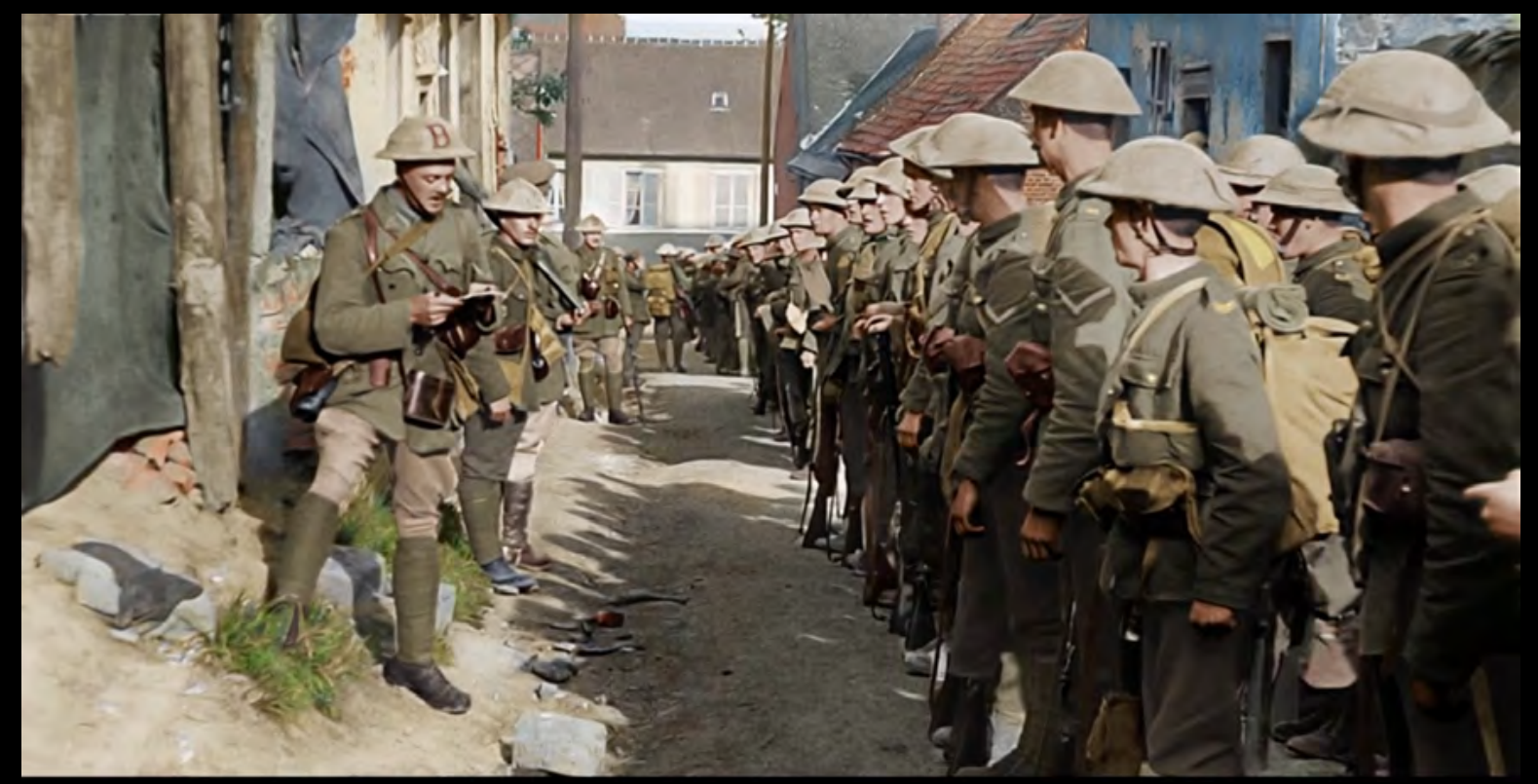

Fig. 2: Images that emphasize perspectival lines have been selected for Jackson's film. They Shall Not Grow Old (Peter Jackson, 2018).

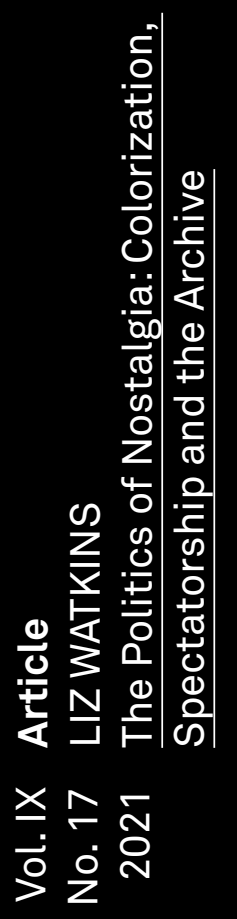


Fig. 3: The transition

from black-and-

white to colorization occurs 25:20 mins into

the film. They Shall Not Grow Old (Peter Jackson, 2018).
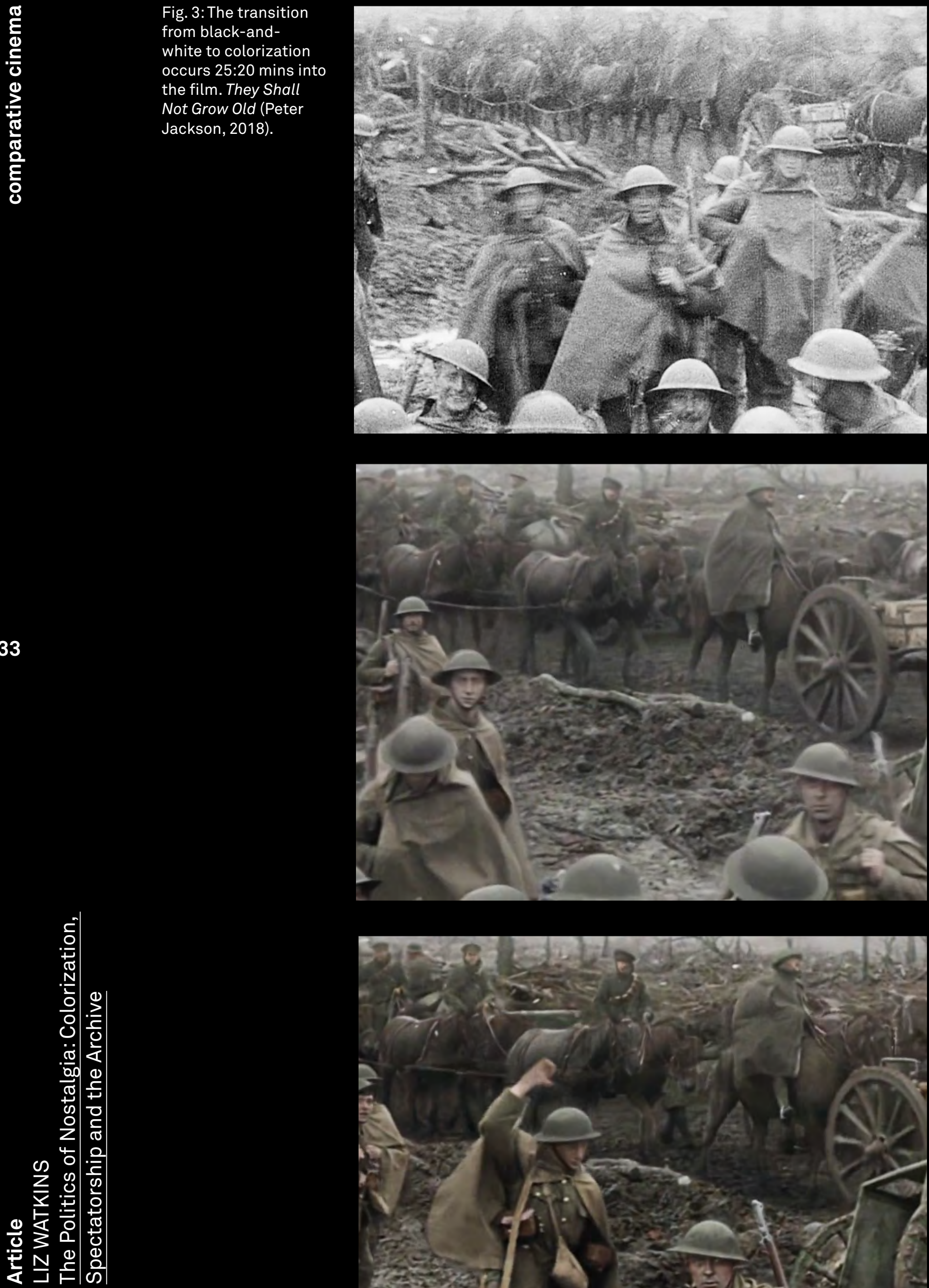

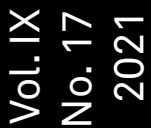

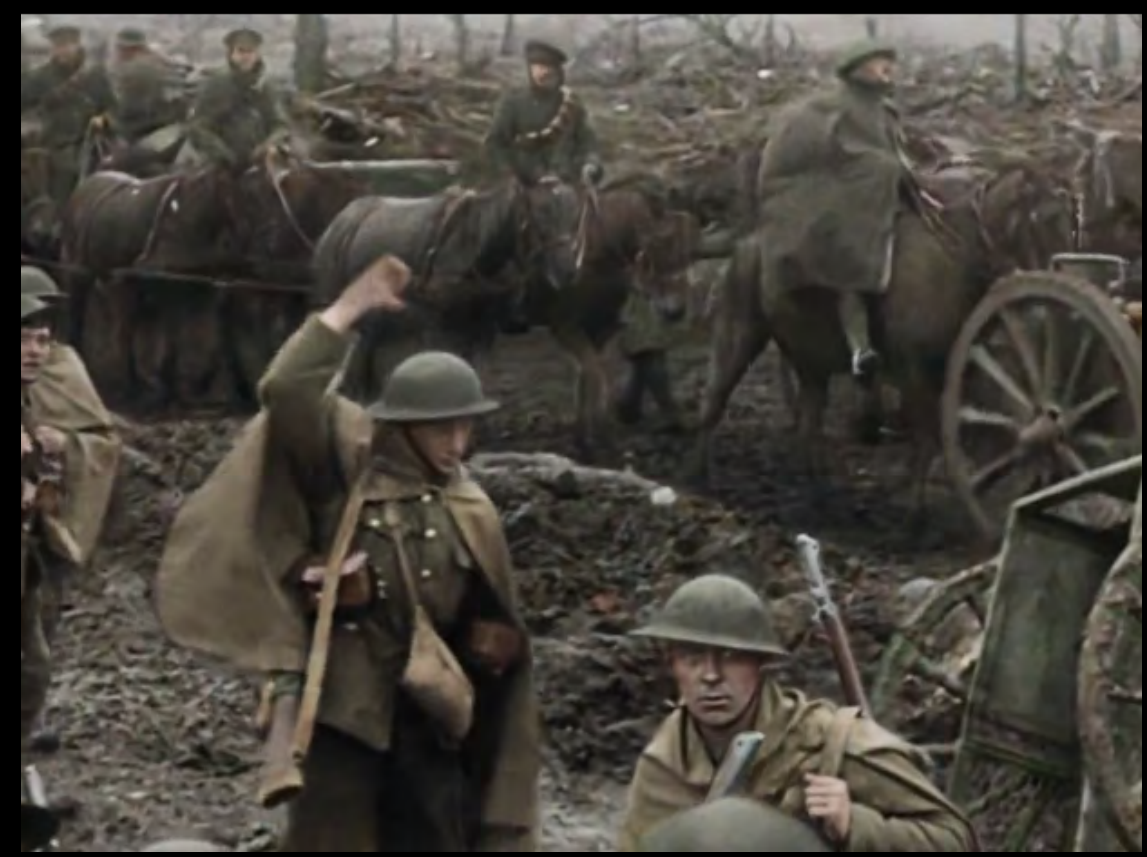


and historical record into stereotypical images, a recidivist approach that reiterates the politics contemporary to the First World War in the screening of archival materials as part of a mythologizing practice.

The shift from a black-and-white to colorized image proposes not only a temporal transition, from past to present, but a perceptual shift toward a more sensory use of color and editing that is like fiction film: a synthesis and effect of the holistic expression of Jackson as the director, another author, secondary to the registration and exhibition of the War Office Cinematograph Committee film. The artifice of deterioration effaces those aspects of the film that form a material record of the historically specific environment in which it was made. The digital copies of archived film have been edited to emphasize distortion in a way that diminishes the variations in light and shadow that would otherwise differentiate between figure and ground. The editing of this sequence constructs a transition from the textured surface of a film image (blurred, out of focus, using the paraphernalia of analogue film), into the clear delineation of perspectival lines that configure the optical illusion of space (Napper 2021, 213). The use of colorization and editing alters the aesthetics and narrative form of the film archive in an affective appeal to a spectator contemporary to the centenary of First World War.

In his study of the way that the applied colors (tinting, toning) of silent film are disassociated from photographic realism, yet employed to emotional effect, Joshua Yumibe revisits Terry Eagleton's notes on aesthetics. Eagleton examines aesthetics as a "discourse of the body" that pertains to a range of perceptions and sensations of which "color is a crucial component of visuality" (Eagleton quoted in Yumibe
2012, 9). In They Shall Not Grow Old, editing techniques are used to construct a presentational aesthetic that is strategic in its interleaving of simulacra of detritus and digitally applied colors to construct a film that variously sublimates and highlights details within the image. The transition from a black-and-white to a colorized image underscores a shift from the textured surface and sensory appeal of a haptic image to optical visuality, a strategy that is determined to elicit an emotional response in the spectator. The effects of viewing moving image files as they shift between low resolution and optical clarity has been explored by Laura $U$. Marks (2002), not as a dichotomy of visuality, but as a mode drawing the spectator into a continual process of changes between haptic and optical images. The movement between the textural surface of the film image (the scratches and grain of the archive film that Jackson [14-18 NOW 2019] has described as "bad black-and-white") was, in the transition to the colorized image, exaggerated by digital artefacts. Jackson's team of editors and color graders edited the archive materials to produce an image with sharp contrast, clearly delineated, as a base for colorization. The transition from black-and-white to colorized film uses images that emphasize perspectival lines to construct an illusion of optical space that sublimates the depredation of the image. This section of film retrospectively constructs a narrative of decline that infers the colorization as "restoration" that is deployed to emotional effect. The presentational aesthetic of colorization in Jackson's documentary is in keeping with the dominant teleological model of film history, which privileges technical and authorial innovation through the retrospective positioning of the images and techniques that preceded them in terms of lack (Elsaesser 2016). The 
spectacle of colorization, intriguing to new audiences as "the reworking of definitive moments in their collective cultural history" (Grainge 1999, 625), is drawn into discourse of "restoration" that is problematic in its focus on profilmic space, whilst digital editing and addition of color implement a design that highlights and obfuscates select areas of the image to inflect new meaning on archive materials. The use of linear perspective that Rosen $(2001,17)$ refers to as a compositional device in the representation of space on screen, is one to which a military to topic lends itself: soldiers marching along roads and trenches, the rows of men sat either side of a table, standing in a line either side of a street. The emphasis on perspectival lines creates the illusion of depth of field and facilitates a "more immersive effect" (Jackson quoted in Murphy 2018) for the spectatorship of the 3D and IMAX format listed for the release of They Shall Not Grow Old. ${ }^{8}$

The palette of They Shall Not Grow Old finds its references in the early color processes of still photographs (Autochromes, Paget Plates) contemporary to the First World War and the two-tone graphic designs of British propaganda posters that are used as mattes to form a border for sections of black-andwhite film footage (Fig. 4). Composite photographs, tinted, and exhibited in art galleries as mural enlargements formed contentious, but effective dramatic illustrations during the First World War. Martyn Jolly's detailed study of "Composite Propaganda Photographs during the First World War" connects the "British Official War Photographs in Colour" exhibition 1918 to the work of the War Office Cinematographic Committee and the popular press (Jolly 2003). ${ }^{9}$ Jackson's work echoes the dramatic assemblages of documentary photographs, yet the application of color is used as a mode of enunciation. The voiced recollection of injured and contorted bodies is illustrated by an increase in red hues to signify blood, digitally painted to follow the curvature of the soldier's head. Color is used to highlight and diminish select details: a red line of digitally drawn color both signifies blood and delineates a body otherwise obfuscated by the quality of the film image and detritus of the trench (Fig. 5).

As the conflict intensifies, the mode of presentation alters: closeups, magnified images that have been rendered and digitally reframed from the archive film, emphasize the facial expressions of soldiers near to the frontline. The close-ups, shown in slowmotion and intercut with images of the dead, are demonstrative of an editorial practice associated with the depiction of emotion in fiction film offering "an affective, visceral historical reimagination" (Bronfen 2013, 218) that is configured to an immersive form of spectatorship.

\section{The politics of nostalgia}

The colorized section of film includes imagery of blue skies, children, interspersed with flowers amongst soldiers resting on the ground in a pastoral scene that has a disquieting effect in the representation of trench warfare (Fig. 6). The contradiction of peacefulness and conflict invokes the film-souvenir, postcard-like topics in the midst of an archive of the First World War that combines news reels and the industrial films of the War Office Cinematographic Committee.

Jackson's project purports to reconfigure the hues of the filmed space and photographed body, but constructs a nuanced interpretation of the archival materials as film narrative. Whilst Rosen suggests that the flecks and scratches of archive film are deictic, connecting indexicality to authenticity, Jackson 


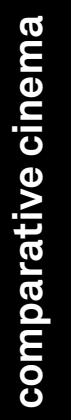

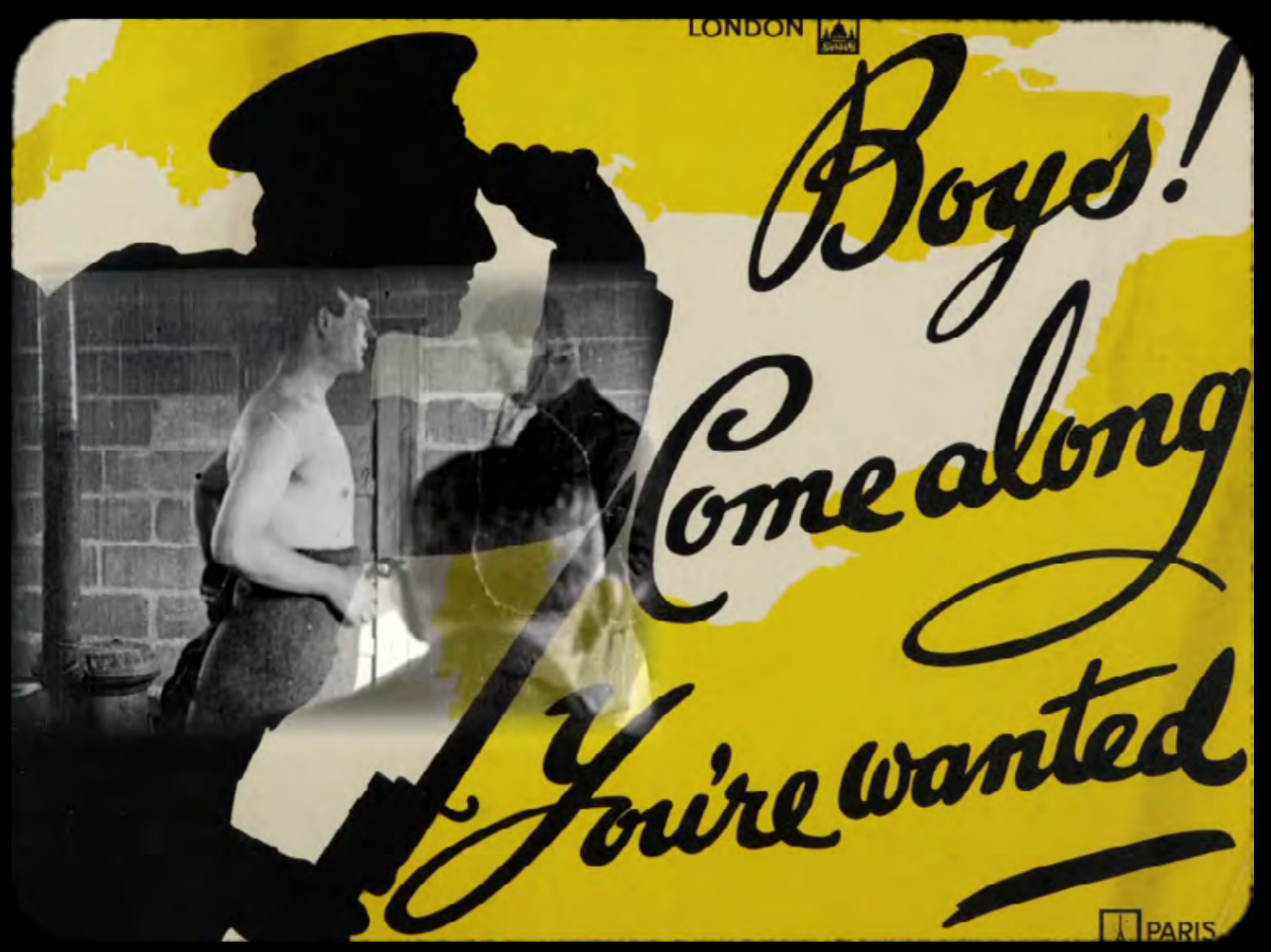

136
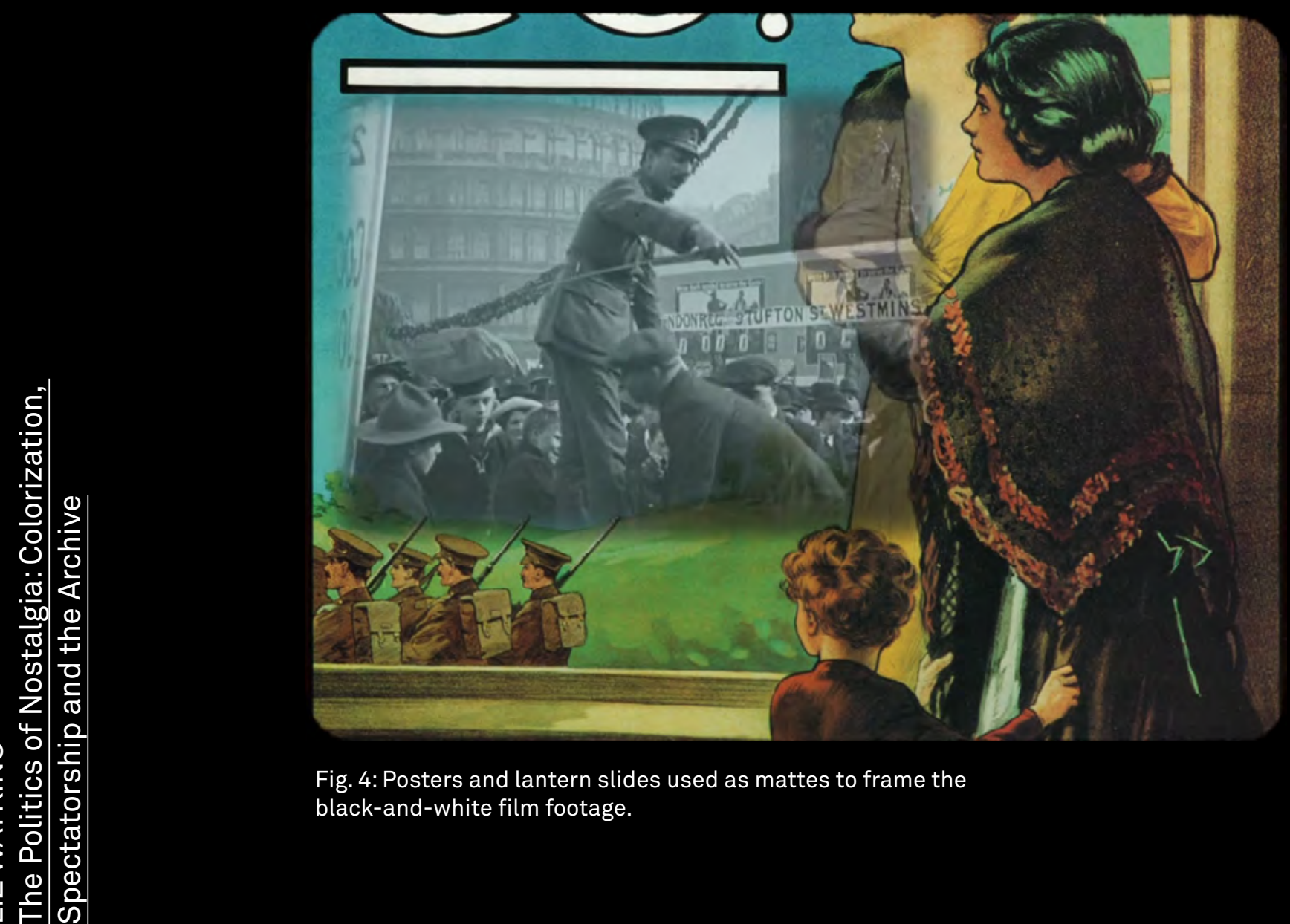

Fig. 4: Posters and lantern slides used as mattes to frame the black-and-white film footage. 
Fig. 5: Color underscores the recollections of conflict in the oral histories: brown hues conceal the body in mud, red highlights the injuries described in the voice-over. They Shall Not Grow Old (Peter Jackson, 2018).
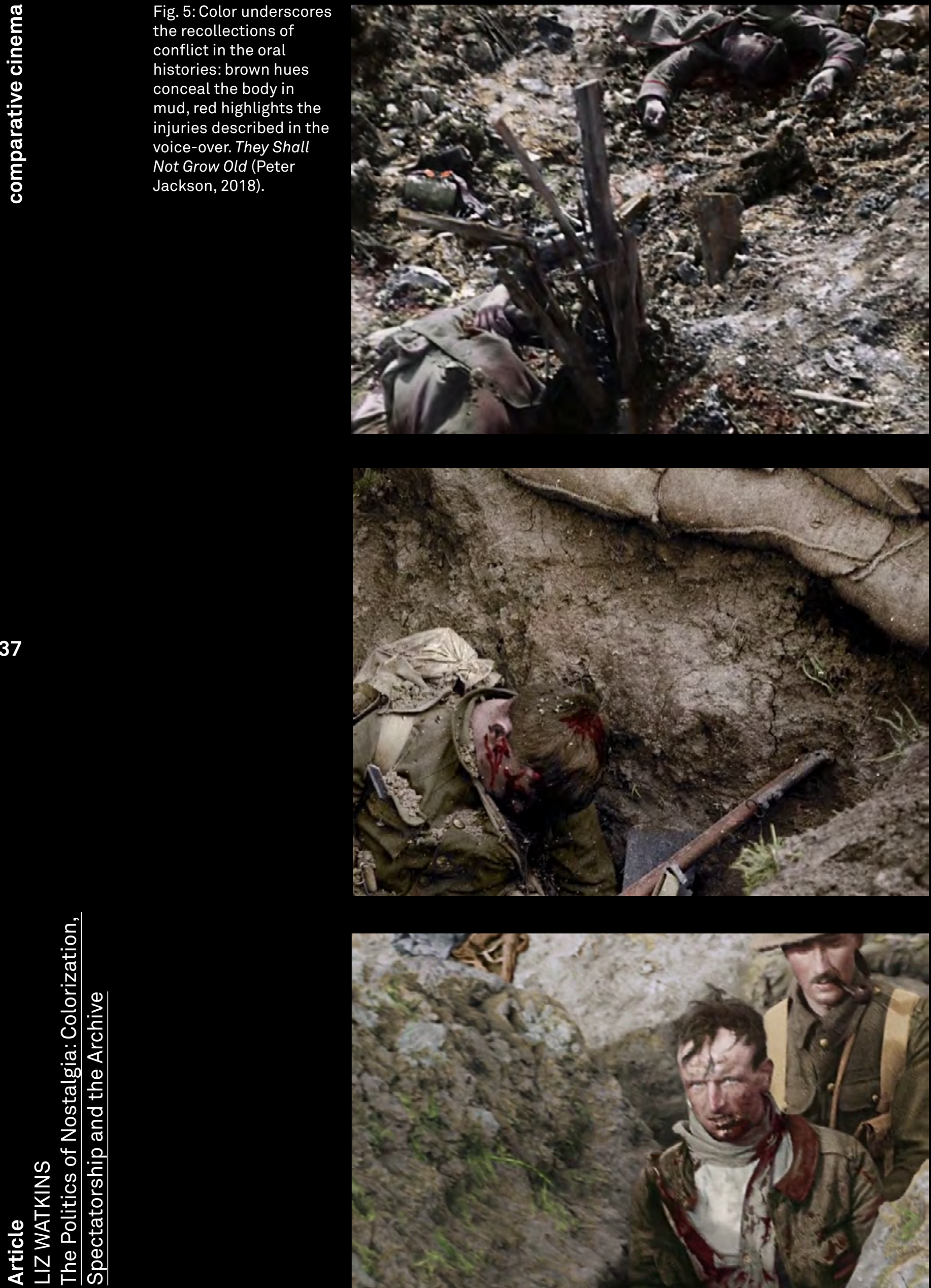

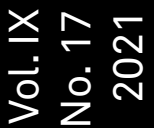

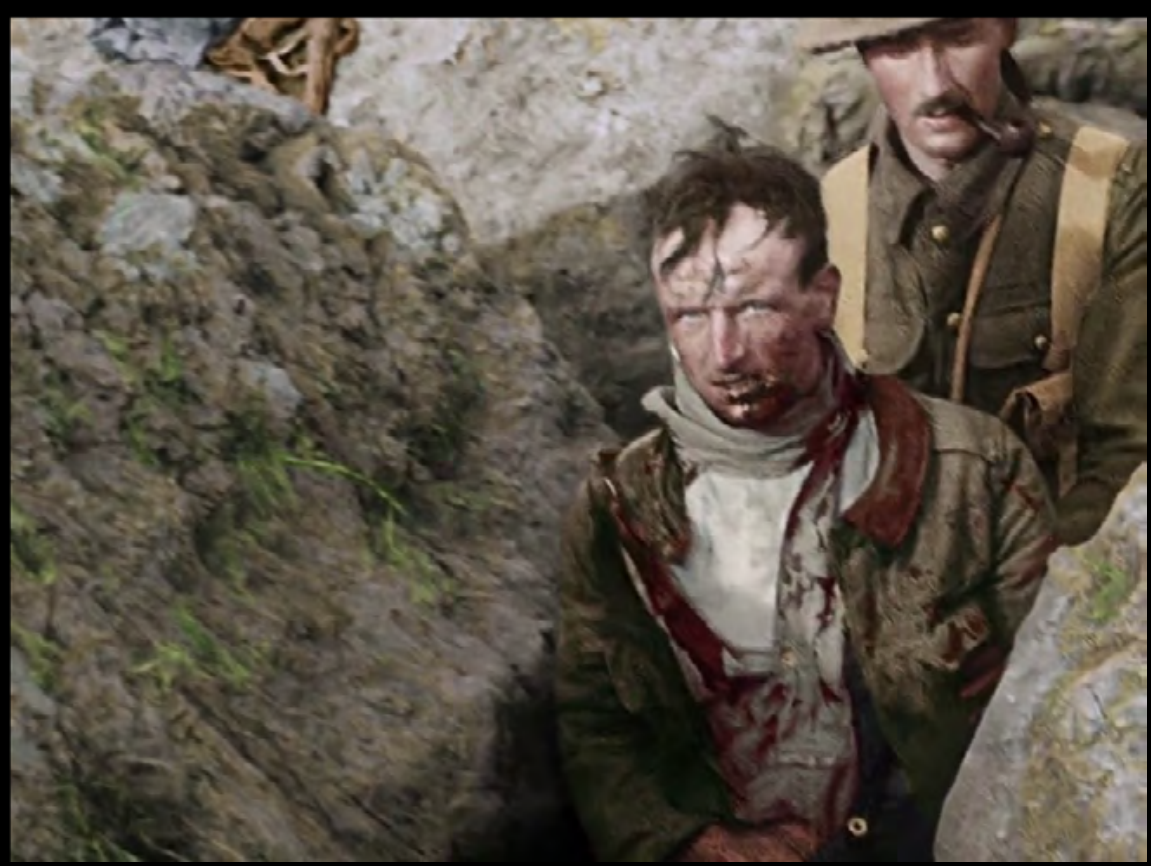




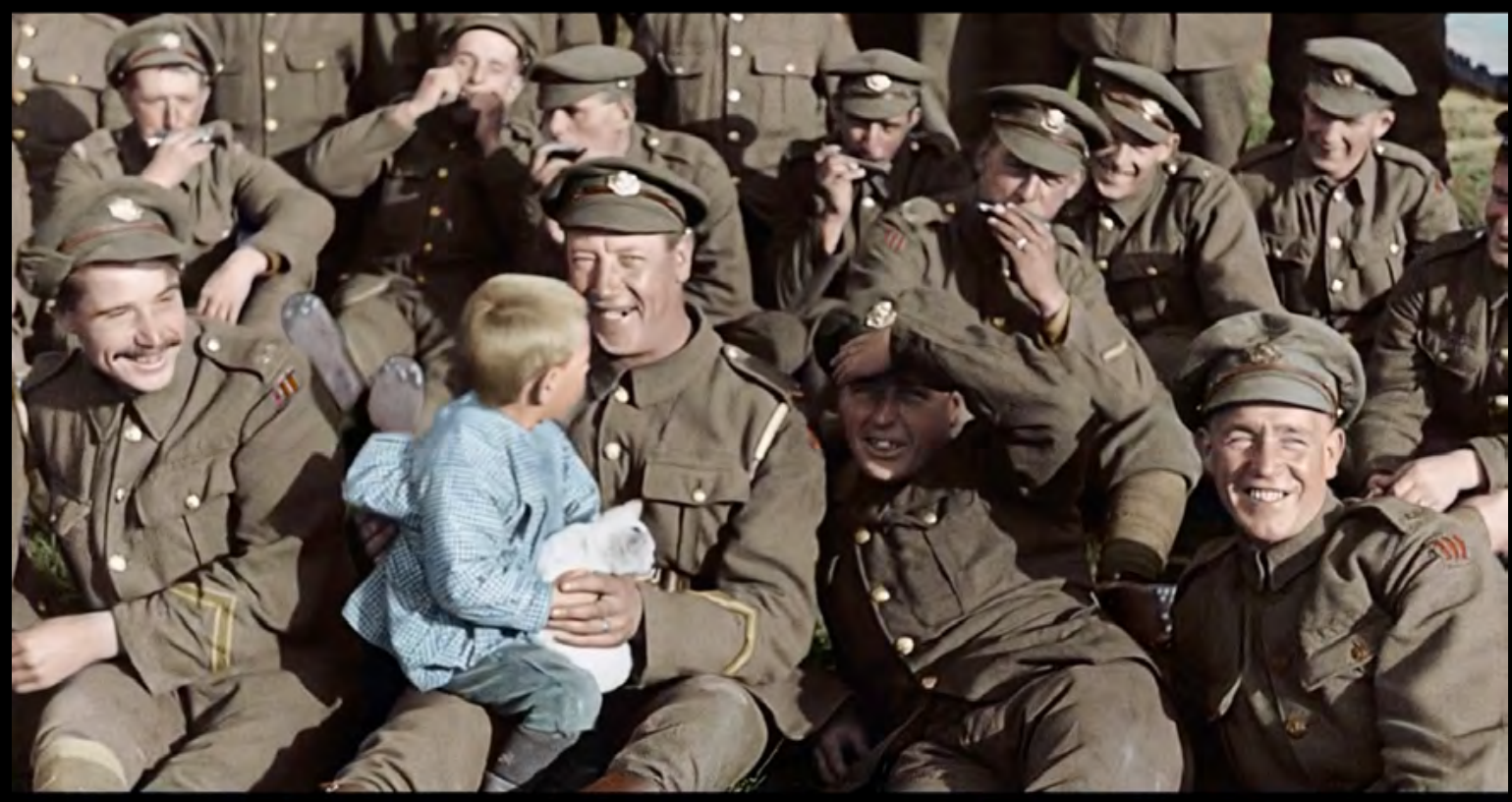

138

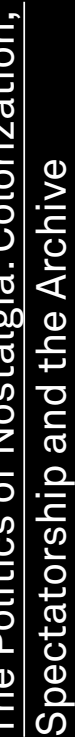

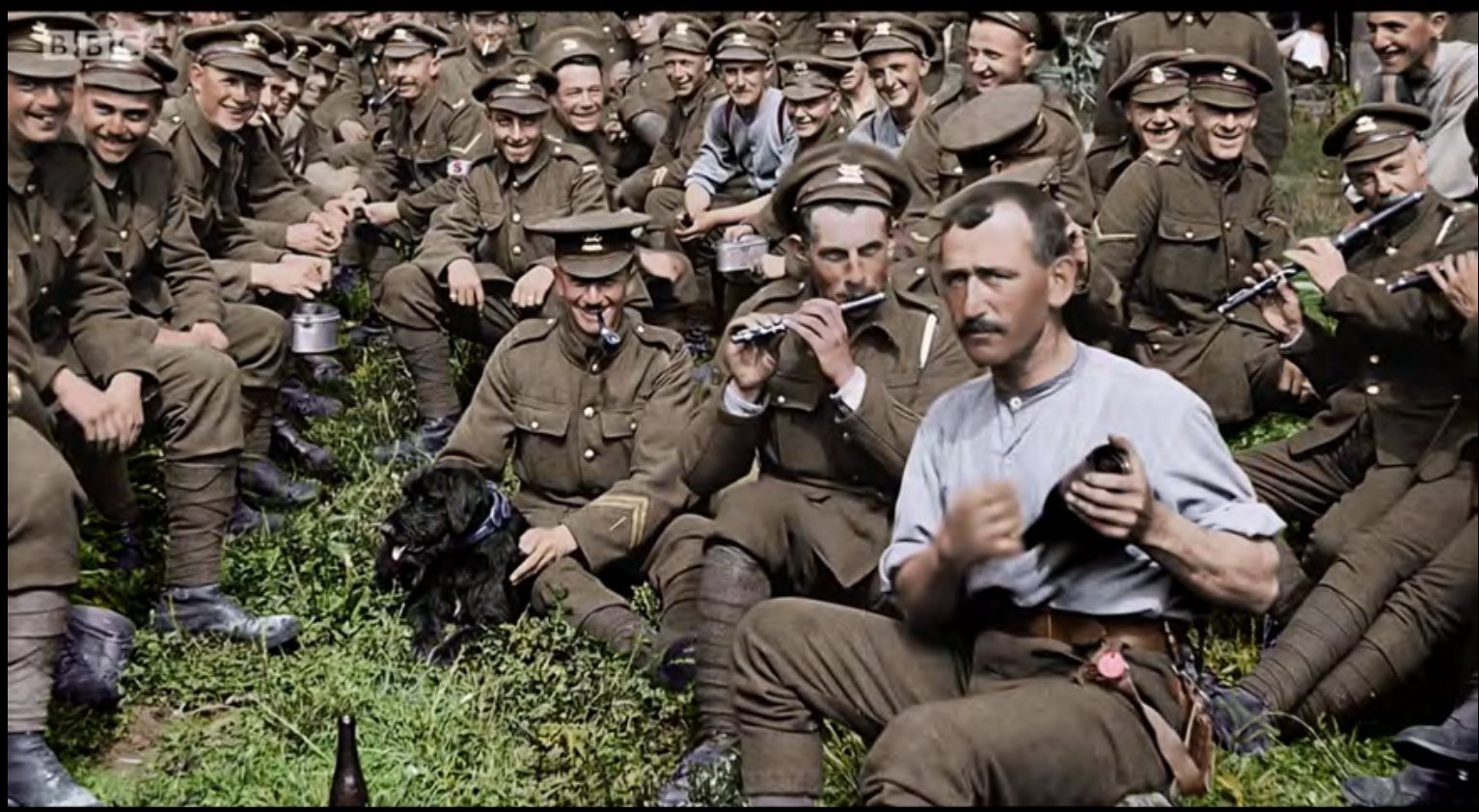

Fig. 6: Pastoral scenes of postcard-like topics. They Shall Not Grow Old

(Peter Jackson, 2018).

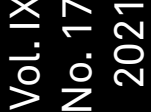


seeks to make the past present, without critical acknowledgement of the political and material history of the film and its exhibition. The deployment of color effaces details that are integral to the indexicality of the photosensitive materials to create an illusion of "natural color," of cinematic realism, that references the hues of First World War magic lantern slides to imply the authenticity of colors selected, yet overlooks the specificity of orthochromatic film stock as a translation of the photographed space. The construction of a color image as "natural" or universal appears normalizing, but is ideologically complicit. The affectivity of this color scheme, like "the discursive power of the epic is not to be found in the specificity and accuracy of its historical detail," but the idea of "re-cognizing oneself as a historical subject of a particular kind" (Sobchack 1990, 28). The sensuous use of colors that Yumibe notes of early film intersect with Sobchack's study of the historical epic. The selection, digitization and colorization of the images in Jackson's film, which constructs a cohesive geographical tract from England to the Western Front and return to civilian life from fragments of archival film and oral histories, marginalizes contradictory social relations. The complexities of class, gender, and race are sublimated to facilitate the emotional ploy of editing and aesthetics, configuring a form of immersive spectatorship that like the historical epic aims to "experience - not think - that particular mode of temporality which constituted him or her as historical subject" (Sobchack 1990, 29). The construction of a "natural color" image that overlooks the role of soldiers from across the British Empire-in its selections and elisions-as Akomfrah states, must be acknowledged and questioned.
The transition from colorized to black-and-white footage, which signals the final section of the film, is visualized as the screen telescopes into an image that is projected on a wall (Fig. 7). The accompanying sound of an analogue film projector alludes to cinematic exhibition, a selfreflexive gesture, as though traversing a threshold through which the diegesis becomes the depiction of a film image. The shift from tableau to diegesis and vice versa sets the central colorized section of the film in parenthesis, a rhetorical ploy that Elisabeth Bronfen $(2013,229)$ finds to be defining of the Hollywood epic. The transition, from the silhouette of soldiers and artillery against the orange and pink hues of a sunset into a scene projected in the cinema, then, is a reflexive authorial gesture that configures an experiential field "that is in as well as about history" (Sobchack 1990, 27). The subjectivizing effects of color and editing imply a particularized relation to the film, yet the potential of utilizing the narrative to formulate a critical historical context for viewing the War Office Cinematographic Committee records is overlooked. Yet, the film is resonant of Frank Hurley's photograph of infantry moving forward to take up front line positions at Hooge October 1917 (Hurley 1917). The editing of the IWM archive echoes Rosen's notes on the way that "socialized understanding of the other, of the distant in time and space, has been built in the very conversions between document and diegesis" (Rosen 2001, 197).

The interpretation of the IWM archive into the audio-visual form of Jackson's They Shall Not Grow Old, which is tailored to a spectatorship contemporary to the centenary of the First World War, perpetuates the revanchism of white British historiography. The response of the spectator is not dependent 
Fig. 7: The transition from the colorized footage into an image on the wall.

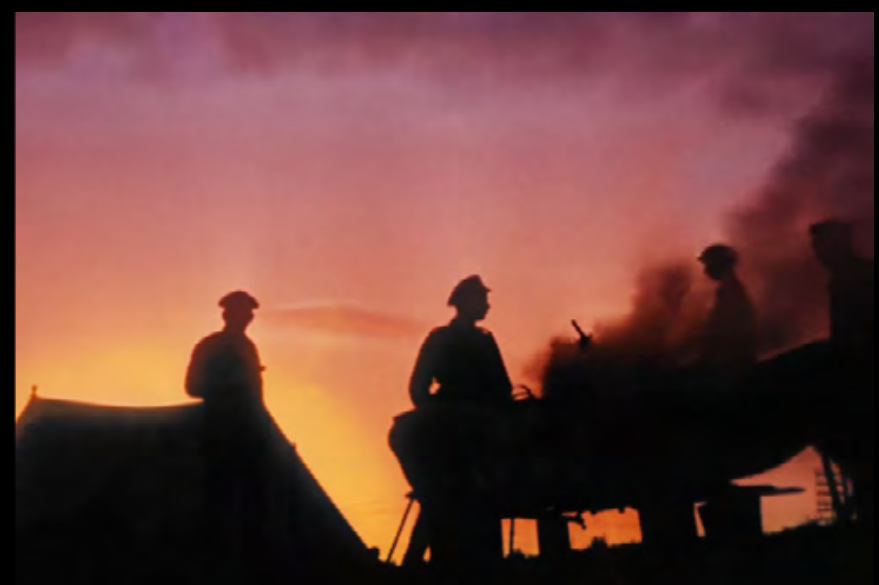

Nearly

e million British and Empire servicem were ksilled between 19)14 and 1918.

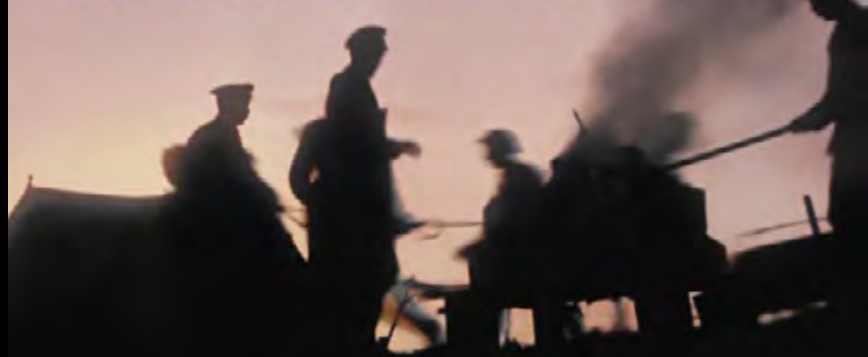

Neasly

one million British and Empire servicemes were killed between 1914 and 1913.
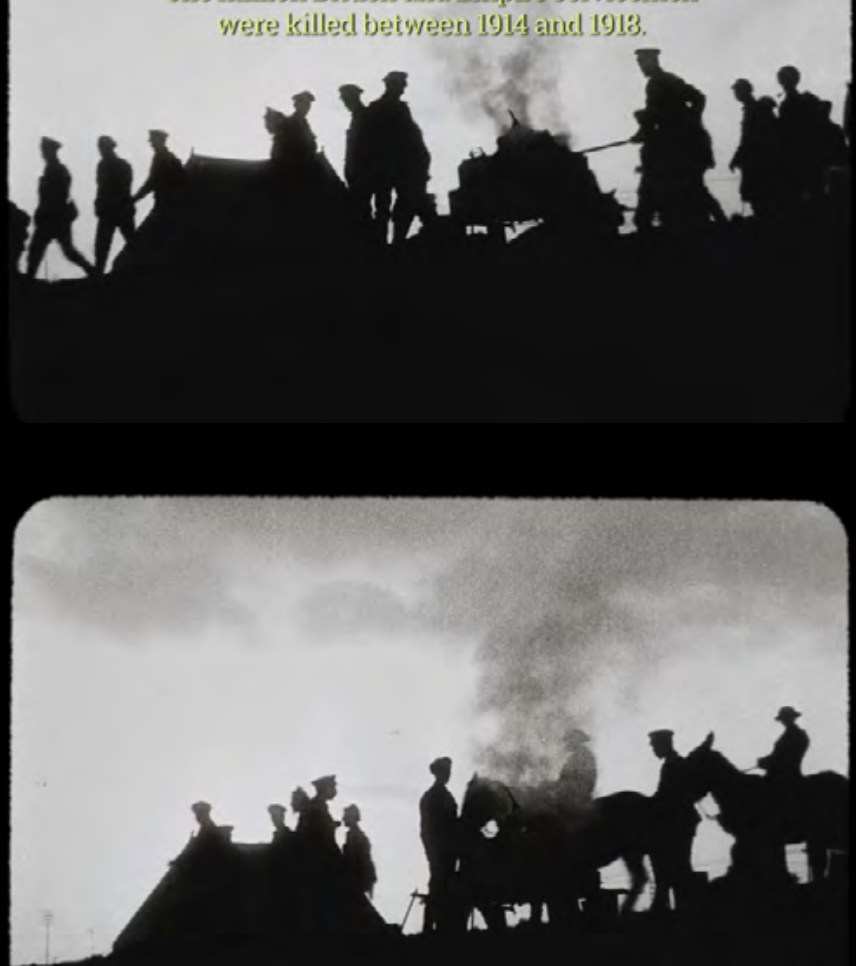

$x \wedge$

क्षें 
on recognition of an individual on screen, but as Hammond writes "on recognizing and empathizing with his plight and resigning him to his destiny" $(2011,35)$. The colorization and editing of They Shall Not Grow Old elicits a private response in public mourning-the commemorative aspect of the film is effective-yet acts through the reiteration of propaganda and elisions in the narrative form of the film. Jackson's approach to color enacts a politics of nostalgia, employing an attendant rhetoric of lack that "posits a decline that appeals" (Grainge 1999, 622) to the restoration of a politically serviceable idealized past at a time of uncertainty. The title of Jackson's film, which is a reiteration of Laurence Binyon's 1914 poem For the Fallen (Binyon 1914) was employed as a cultural reference in the political rhetoric of the British prime minister, Boris Johnson, in the wake of the 2016 referendum on membership of the European Union. ${ }^{10}$ Johnson's 2020 invocation of Binyon's poem sublimated its historical specificity to the affective aspects of nostalgia in the economy of information and populist politics (BBC 2020). ${ }^{11}$

The IWM First World War exhibit "Life on the Line" does include footage from Peter Jackson's They Shall Not Grow Old alongside film from the First World War archives that have been digitized, but not colorized. The exhibition forms part of the Big Picture Show at the IWM North and embeds the images in an "immersive surround sound and 360 degree, 27 foot tall, projection that brings personal experiences of conflict to life" (Imperial War Museums n.d.b.). The invocation of spectator experience remains in the marketing and format of the exhibition, yet the critical historical context offered by the museum differs from the artificiality of space that is articulated in the colorized cinematic image. Colorization is an effective form of public engagement and commemorative practice. However, the prioritization of historicity, emotion, and the subjective response of a spectator to the historiographic form of They Shall Not Grow Old contemporary to the centenary of the First World War is problematic. It overwrites the history of conflict, labor and the politics of cinema exhibition that were integral to the formation of the War Office Cinematographic Committee and their work. In Jackson's film the disparate battles and social complexity of allied forces and their combatants are sublimated to a coherent and concise narrative that elides the work and death of women, and the soldiers and carriers noted in Akomfrah's multiscreen installation. The characteristics of photochemical filmstock as a material record of the First World War and in the context of a film that is enunciated by color forms a "junction of desire and politics" (Rosen $2001,176)$ that has the potential to become a site of resistance, to provoke the critical thinking that Sobchack demands. It is this particular use of colorization that Jackson's film does not explore, preferring to set it aside, in favor of a tract of nostalgia that is determined to close historical distance.

1/ The online forum Reddit includes a subreddit called $\mathrm{r}$ /Colorization that has seen an increase in membership from 82,454 members on 7 July 2019 to 311,836 members on 21 March 2021. The membership of a second subreddit, called r/ColorizedHistory has increased from 482,944 members on 7th July 2019 to 611,755 members on 21 March 2021.

2/ The Maltese Falcon was colorized by Color Systems Technology Inc/TBS in 1986 and marketed as part of the Color Classic Network of 85 TV stations. 
3/ Research for Jackson's film included consultation of oral history projects at the Imperial War Museum and a collection of BBC interviews with servicemen, which Jackson and Park Road Post Production selected, re-recorded and edited.

4/ Arnold, as editor of the British Journal of Photography, is writing about the work of "camera artist" H.G. Ponting for the British Antarctic Expedition 1910-13, using orthochromatic film and photographic materials and filters, in the years immediately prior to the First World War.

5/ Napper (2018c) notes that the film footage used in They Shall Not Grow Old had been the subject of conversation and the production of $4 \mathrm{~K}$ digital scans prior to the production of Jackson's film.

6/ "They Shall Not Grow Old by Peter Jackson Toolkit" (Imperial War Museums, n.d.c.) includes sections on "Friendship," "Impact," "Reconciliation" for Key Stage 3 (S1 \& S2) subjects including English and History. See also Ward 2018.

7/ The oral histories of the First World War were archived by the IWM and BBC in the 1960 s.

8/ The film was converted to 3D by Stereo D.

9/ Jolly writes that Beaverbrook was Chair of the British War Office Cinematographic Committee, owner of the Daily Mail and the first Minister of Information in Britain (1918).

10/ This poem includes the line "They shall grow not old, as we that are left grow old." The syntax of Jackson's film title is different. The line in Binyon's poem suggests loss and remembrance as those that survived, later, recall the death of their comrades and combatants, whilst Jackson's film seeks to diminish historical distance, to make the past present.

11/ The phrase "they shall not grow old" was utilized by Johnson in a remembrance service speech marking the 75th year since the end of conflict with Japan in 1945.

\section{References}

14-18 NOW. 2018. "They Shall Not Grow Old Official Trailer." 16 October. https:// www.1418now.org.uk/commissions/new-film-peter-jackson/ [accessed November 18, 2021]

14-18 NOW. 2019. “\#TheyShallNotGrowOld - Peter Jackson's BAFTA-Nominated film." YouTube, 8 February. https://www.youtube.com/watch?v=kDO_JWPis4k [accessed November 18, 2021]

Allison, Tanine. 2021. "Digital Film Restoration and the Politics of Whiteness in Peter Jackson's They Shall Not Grow Old." Quarterly Review of Film and Video (May): 1-26. https://doi.org/10.1080/10509208.2021.1908106

Amaral, Marina, and Dan Jones. 2018. Colour of Time: A New History of the World 1850-1960. London: Head of Zeus. 2020. All the World Aflame: the Long War 1914-1945. London: Apollo.

Arnold, H.J.P. 2004. "Antarctic Pioneer." In With Scott to the South Pole, The Terra Nova Expedition 1910-1913, The Herbert Ponting Photographs, 203-23. London: Bloomsbury.

Barthes, Roland. 2000. Camera Lucida. London: Vintage Books.

Bazin, André. 1967. "The Ontology of the Photographic Image." In What is Cinema? Vol. 1, translated by Hugh Gray, 9-16. Berkeley: University of California Press.

BBC. 2020. "VJ Day: UK commemorates 75th anniversary as royals lead tributes." BBC News, 15 August. https://www.bbc.co.uk/news/uk-53786610 [accessed November 18, 2021] 
Binyon, Laurence. 1914. "For the Fallen.” The Times, issue. 40642, 21 September, 9.

Bronfen, Elisabeth. 2013. "Monumental Cleopatra: Hollywood's Epic Film as Historical Re-imagination." Anglia 131(2-3): 218-35. https://doi.org/10.1515/ anglia-2013-0033

Cherchi Usai, Paolo. 2001. The Death of Cinema: History, Cultural Memory and the Digital Dark Age. London: British Film Institute

Cooper, Roger. 1991. "Colorization and Moral Rights: Should the United States Adopt Unified Protection for Artists?" Journalism Quarterly 68(3): 465-73. https:// doi.org/10.1177/107769909106800317

Edgerton, Gary. 2000. “'The Germans Wore Gray, You Wore Blue’: Frank Capra, Casablanca, and the Colourization Controversy of the 1980s." Journal of Popular Film and Television 27(4): 24-32. https://doi.org/10.1080/01956050009602812

Edwards, Elizabeth. 2019. "Review: The Colour of Time: A New History of the World 1850-1960." History of Photography 43(3): 331-32. https://doi.org/10.1080/0 $\underline{3087298.2020 .1732059}$

Elsaesser, Thomas. 2016. Film History as Media Archaeology, Tracking Digital Cinema. Amsterdam: Amsterdam University Press. https://doi. org/10.1017/9789048529964

Gendler, Jason. 2013. “'Are my eyes really brown?' The Aesthetics of Colorization in Casablanca." in Color and the Moving Image: History, Theory, Aesthetics, Archive, edited by Simon Brown, Sarah Street, and Liz Watkins, 199-208. New York: Routledge.

Grainge, Paul. 1999. "Reclaiming Heritage: Colourization, Culture Wars and the Politics of Nostalgia." Cultural Studies 13(4): 621-38. https://doi. org/10.1080/095023899335077

Haggith, Toby. 2011. "The Dead, Battlefield Burials and the Unveiling of War Memorials in Films of the Great War Era." In British Silent Cinema and the Great War, edited by Michael Hammond and Michael Williams, 145-59. London: Palgrave Macmillan. https://doi.org/10.1057/9780230321663_11

Hammond, Michael. 2011. "The Battle of the Somme (1916): an Industrial Process Film that 'Wounds the Heart."' In British Silent Cinema and the Great War, edited by Hammond and Michael Williams, 19-38. London: Palgrave Macmillan. https://doi.org/10.1057/9780230321663_2

Hammond, Michael, and Michael Williams. 2011. "Goodbye to All That or Business as Usual? History and Memory of the Great War in British Cinema." In British Silent Cinema and the Great War, edited by Hammond and Williams, 1-34. London: Palgrave Macmillan.

Hurley, Frank. 1917. "Infantry moving forward to take up front line positions at evening, their images reflected in a rain-filled crater at Hooge, October 1917," half glass plate, black-and-white photograph. PIC FH/672 LOC Cold Store PIC Hurl 42/5. National Library of Australia. https://nla.gov.au/nla.obj-158873266/view [accessed November 18, 2021]

Imperial War Museums. n.d.a. "The Role of Empire and Commonwealth Troops during the Battle of the Somme." Imperial War Museum. https://www.iwm.org.uk/ history/the-role-of-empire-and-commonwealth-troops-during-the-battle-ofthe-somme [accessed April 1, 2021] 
. n.d.b. "Life on the Line: with Footage from Peter Jackson's They Shall Not Grow Old." Imperial War Museum North. https://www.iwm.org.uk/events/ life-on-the-line-with-footage-from-peter-jacksons-they-shall-not-grow-old [accessed January 23, 2021]

. n.d.c. "They Shall Not Grow Old by Peter Jackson." IWM Teaching Resource for Schools 14-18NOW WW1 Centenary Art Commissions. https:// www.1418now.org.uk/learning-engagement/peter-jackson-film/ [accessed November 18, 2021]

. 2018a. "John Akomfrah on Mimesis African Soldier." Part of the Making a New World season of exhibitions, Imperial War Museum London, 21 September 2018 - 31 March 2019. https://www.iwm.org.uk/history/John\%20Akomfrah\%20 on\%20Mimesis\%3A\%20African\%20Soldier [accessed June 20, 2021]

.2018b. "Policy on the Colourisation of original black and white film and photographs for licensing for use in commercial projects." Imperial War Museum. https://www.iwm.org.uk/sites/default/files/files/2018-05/IWM\%20Policy\%20 on\%20the\%20colourisation\%20 of\%20black\%20and\%20white\%20film\%20 and\%20photographs\%202018.pdf [accessed April 29, 2021]

Jackson, Peter. 2018a. "Peter Jackson colourises World War One footage." Interview by BBC Click, 15 October. https://www.youtube.com/ watch?v=EYleactIMWo [accessed November 18, 2021]

.2018b. Interview by 14-18 NOW. YouTube. https://www.youtube.com/ watch?v=vn6HrP_LTu8 [accessed November 18, 2021]

Jolly, Martyn. 2003. "Composite Propaganda Photographs during the First World War." History of Photography 27(2): 154-65. https://doi.org/10.1080/03087298.200 $\underline{3.10443266}$

. 2018. "Corrosive Colourisation." Martyn Jolly, 24 January. https:// martynjolly.com/2018/01/24/corrosive-colourisation [accessed June 20, 2021]

Lloyd, Jordan, and Wolfgang Wild. 2018. History as they Saw it: Iconic Moments from the Past in Colour. San Francisco: Chronicle Books.

Marks, Laura U. 2002. Touch: Sensuous Theory and Multisensory Media. Minneapolis: University of Minnesota Press.

Murphy, Mekado. 2018. "How Peter Jackson Made WWI Footage seem Astonishingly New with They Shall Not Grow Old." New York Times, 16 December.

Napper, Lawrence. 2018a. "They Shall Not Grow Old (Peter Jackson, 2018) And The Elephant In The Room." IAMHIST Blog, 23 October. https://iamhist. net/2018/10/they_shall_not_grow_old/ [accessed November 18, 2021]

. 2018b. "They Shall Not Grow Old." At the Pictures, 5 October. https:// atthepictures.photo.blog/2018/10/05/they-shall-not-grow-old/ [accessed November 18, 2021]

.2018c. "They Shall Not Grow Old (2) The abject archive ... the sacred archive." At the Pictures, 12 October. https://atthepictures.photo. blog/2018/10/12/they-shall-not-grow-old-2-the-abject-archive-the-sacredarchive/ [accessed November 18, 2021]

. 2021. "The Battle of the Somme (1916) and They Shall Not Grow Old (2018): archivists, historians, lies and the archive." Studies in European Cinema 18(3): 212-21. 
"Official Pictures. The War Office Cinematograph Committee" (advertisement). 1917. Kinematograph and Lantern Weekly, Thursday 31 May, 24.

Rosen, Philip. 2001. Change Mummified, Cinema, Historicity, Theory. Minneapolis: University of Minnesota Press.

Sheppard, Adam. 2021. "The Art of Digitising War." ITPro. 27 May. https://www. itpro.co.uk/infrastructure/server-storage/359685/the-art-of-digitising-war [accessed June 30, 2021]

Sherman, Barry, and Joseph Dominick. 1988. "Perceptions of Colorizations." Journalism Quarterly 65.4 (Winter): 976-80. https://doi. org/10.1177/107769908806500422

Sobchack, Vivian. 1990. “'Surge and Splendour’: A Phenomenology of the Hollywood Historical Epic." Representations 29 (Winter): 24-49. https://doi. org/10.2307/2928417

Valentini, Valentina I. 2019. "How Peter Jackson's 'They Shall Not Grow Old' Crew Carefully Restored Archival Footage.” Variety, 8 February.

Ward, Helen. 2018. "Peter Jackson makes First World War film for Schools." tes, 18th October. https://www.tes.com/news/peter-jackson-makes-first-world-warfilm-schools [accessed November 18, 2021]

Wasson, Haidee, and Charles R. Acland. 2011. Useful Cinema. Durham and London: Duke University Press.

Yumibe, Joshua. 2012. Moving Color, Early Film, Mass Culture, Modernism. New Brunswick, NJ and London: Rutgers University Press. 